\title{
Archaeology as a Renovation Element of the Railway Stations Areas
}

\author{
By Pasquale Miano*
}

The construction of the railway lines in archaeological sites is featured extensively in the European territory. In many cases it was a destructive and upsetting presence. Only recently we have spoken about "living together", so the issue has been approached in terms of functional but also cultural integration. Today this attitude has become common, above all when the question about the building of new railway lines arises. But, there is also another problem relating to the renewal of railway areas, and in particular the station areas, which is more complex and complicated. This new requirement imposes a different perspective on the archaeological areas subject to past destructions, which are involved and that can take on a completely different role than in the past. This idea starts from the finding that the overlap of nodal infrastructure levels to the ruins of ancient settlements is not random, but derives from the strategic vocation of the particular area, invested over time by different urbanizations and constructions. It is also important to realize that the railways, with their stations, represent an important potential element of connection between the archaeological areas, which in a wide territory can be interpreted as a network. On this basis, this research identifies some areas of the southern Italian territory, in which these aspects are particularly clear and significant to define a project of an integrated urban and territorial renewal. Through this in-depth analysis we intend to evaluate the archaeological potential as a factor able to restore the configuration and the functional contents of the station areas and at the same time to give a new impulse and a new role to the railway line in crisis or undergoing decommissioning.

\section{Introduction}

The theme of the disruptive, shattering and destructive presence of rail infrastructure in areas that have proved to be of fundamental importance from a historical and archaeological standpoint, is featured extensively in the European territory. It is only recently that we have tried to mitigate the impact of this difficult coexistence, often revealed in a totally fortuitous way, for which the theme was addressed in terms of not only functional, but also cultural integration. However the design solutions, in which it has reached an effective balance, are not yet numerically relevant: archeology was often only meant as the furnishings of the stations included in well-researched showcases, other times engineering solutions are preferred, but are unable to effectively

* Professor, University Federico II of Naples, Italy. 
control the changes, conceal or cover the archaeological findings. Instead you must seek, through the project, a real interconnecting mechanism, which means that the excavations and the archaeological finds must assume a clear role in the renovation and upgrading interventions of railway areas, and in particular of the station areas. This requirement imposes a different perspective on the archaeological sites, which may be involved in these transformative processes in an active way, if you break down the many barriers that continue to isolate the archaeological presence in various urban locations.

In this work approach and involvement it is necessary to start from the fact that the overlapping of the ancient artifacts of railway infrastructure elements is not random, but derives from the vocation of the strategic areas, during the time invested by the different urbanizations and buildings. In a synthesis there is a cyclical return that intermittently emphasizes places of ancient settlement that, in morphological and settlement terms, have a particular importance, which manifests itself several times over time. This relevance imposes a broadening of the horizons of the project to wider territories, often littered with archaeological findings and rigidly crossed by the railways. In this context it is important to consider that the railways, with their stations, are an important potential factor linking the archaeological sites, which in a vast territory may be finally re-read as a real settlement system, as a braided and articulated network, not limited to self-treatment of individual episodes.

This condition characterizes different areas of the southern Italian territory, such as the archaeological sites of the Ionian Calabria, for example, in which the territorial relations framework of land formerly established seems particularly clear and relevant for the purposes of a project of integrated urban and territorial renewal. Or in Campi Flegrei, where the Cumana railroad cut the minor amphitheater of Pozzuoli in two parts, compressed by the recent settlements. But we should go on, mentioning several examples. Through the study of the intersect between rail and archeology, we ultimately evaluate the archaeological potential as a factor able to renew the configuration and the contents of the stations functional areas and, at the same time, to give a new impetus and a new role to the railway lines in crisis or undergoing decommissioning.

The agreement ${ }^{1}$ between the Department of Architecture of the University of Naples Federico II and the Ente Autonomo Volturno Company Ltd., in which the studies for the redevelopment of urban areas of some EAV stations have been developed, has dealt with the emblematic case of the city of Benevento, which is very significant for studying the themes of archeology in railway areas, with particular reference to the station Benevento Appia, where the renovation of the station, seen as "part of the city, can become the basic

1. Agreement Stations and cities. Studies for the redevelopment of urban areas of some Metrocampania stations. Working group: scientific director: Prof. Arch. Pasquale Miano; external consultants: Arch. Pasquale Castaldo, Arch. Valeria Civitillo, Arch. Marina Di Iorio, Arch. Bruna Di Palma. 
point for a comprehensive redesign of the district, for the design of new urban areas" 2 .

\section{The Benevento Appia Station of Naples-Benevento Railway and the Roman Amphitheater}

The Naples-Cancello-Benevento railway line, with a path of about $49 \mathrm{~km}$, serving 14 municipalities, entered into service in 1910 and underwent a limited number of changes, representing a constant reference with respect to the settlements crossed. Over the same period, the settlement situation has changed dramatically and in this processuality the location and configuration of the railway were not irrelevant. In a nutshell it can be said that the railway, large element of innovation and modernity of the late nineteenth century, over a century has been transformed into a non-date element, a delay and difficulty factor, and certainly not an item propulsive. Under these conditions, it does not escape the area of the station Benevento Appia (see Figure 1) on the railway line Naples-Benevento, an elongated area between Via Appia Antica and Via Appio Claudio and placed at the point of maximum geographical compression between rivers Sabato and Calore, quite close to the walled perimeter of the ancient city. The station appears closed within its enclosure, made from a natural perimeter defined by different levels, foreign to any dialogue with its surroundings and with largely insufficient accessibility.

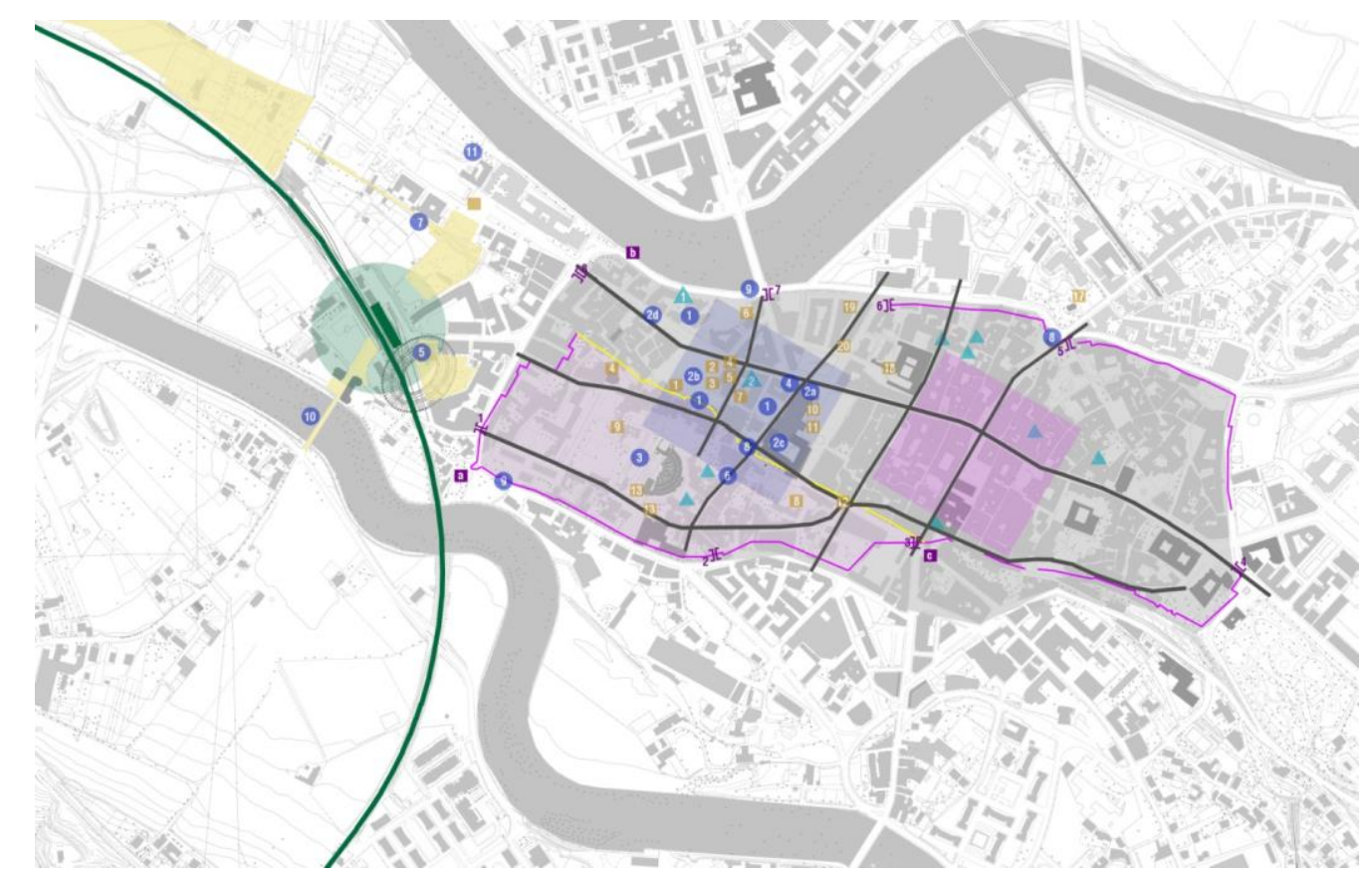

Figure 1. The Benevento Appia Station of Naples- Benevento Railway and the Amphitheater (Author arch. Bruna Di Palma)

2. Christina Mazzoni, Stazioni, architetture 1990-2010 (Milan, Federico Motta Editore, 2001), 55. 
It is a heterogeneous environment, in which only partially visible archeological elements (the outline of the Roman amphitheater, the few columns, the traces of ancient walls scattered in the wide green spaces, the Leproso bridge built by the Romans on the Via Appia, the few remains of the river port on the banks of Calore river) are intertwined and coexist with elements of industrial architecture (such as iron, glass and brick sheds of the former Metalplex), but also by farms and industrial building elements scattered among the green and agricultural fields.

The railway line, with four tracks, two used for passenger service and two for freight service, crossing areas, still an agricultural part of Cellarulo city quarter, is cutting the territory in two parts. They represent a real gap between adjacent areas, one towards the Calore river and the other towards the river Sabato, whilst being in a strategic position to the city, the landscape and the territory.

Despite the station, Benevento Appia represents the strategic center of the whole line, with the executive offices, technical, administrative and outbuildings stores and shops, currently the railway does not play an emerging role in terms of relations and urban operations. The area has a single point of access from the street, with an irregular space in front of the station, which is certainly not configured as a meeting place, but is only used as a car park. Buses, stationed at the parking area with workshop and washing, help to congest this space very messy and lacking of a proper functional organization. In the studies carried out in the agreement, we have highlighted some of the potential of the railway line not adequately considered today: on the one hand as a reservoir of available areas, with the downsizing and streamlining of the tracks and the different warehouses, for the inclusion of public spaces, equipment, activities, of which the different centers have crossed absolute necessity; on the other hand, laying as morphological permanence, being a specific reference in training and development centers, lends itself to become the backbone of urban transformation, can profoundly change the current configuration, redefining many situations long unresolved. These capabilities are evident in the Benevento Appia station, currently strategic only for position, which is necessary to return an urban and territorial role, through appropriate interventions not simply limited to the architectural aspects, but able to trigger a process of regeneration a part of the city in a marginal position, retrieving and renewing relationships between the station, the city and the territory.

\section{A New Network of Relationships: Interconnected Layers and Breakage of the Margins}

However this ambitious project is incomplete, if you do not take into account the significant presence of archaeological remains in the area, which makes it even more significant, and, at the same time, the design approach more difficult and complex: the theme is to relate the different appearances and 
different tracks, searching for a new spatial organization in which the railroad take, at the same time, the character of completed and running infrastructure, but also a place of connection between city, landscape and archeology (see Figure 2).

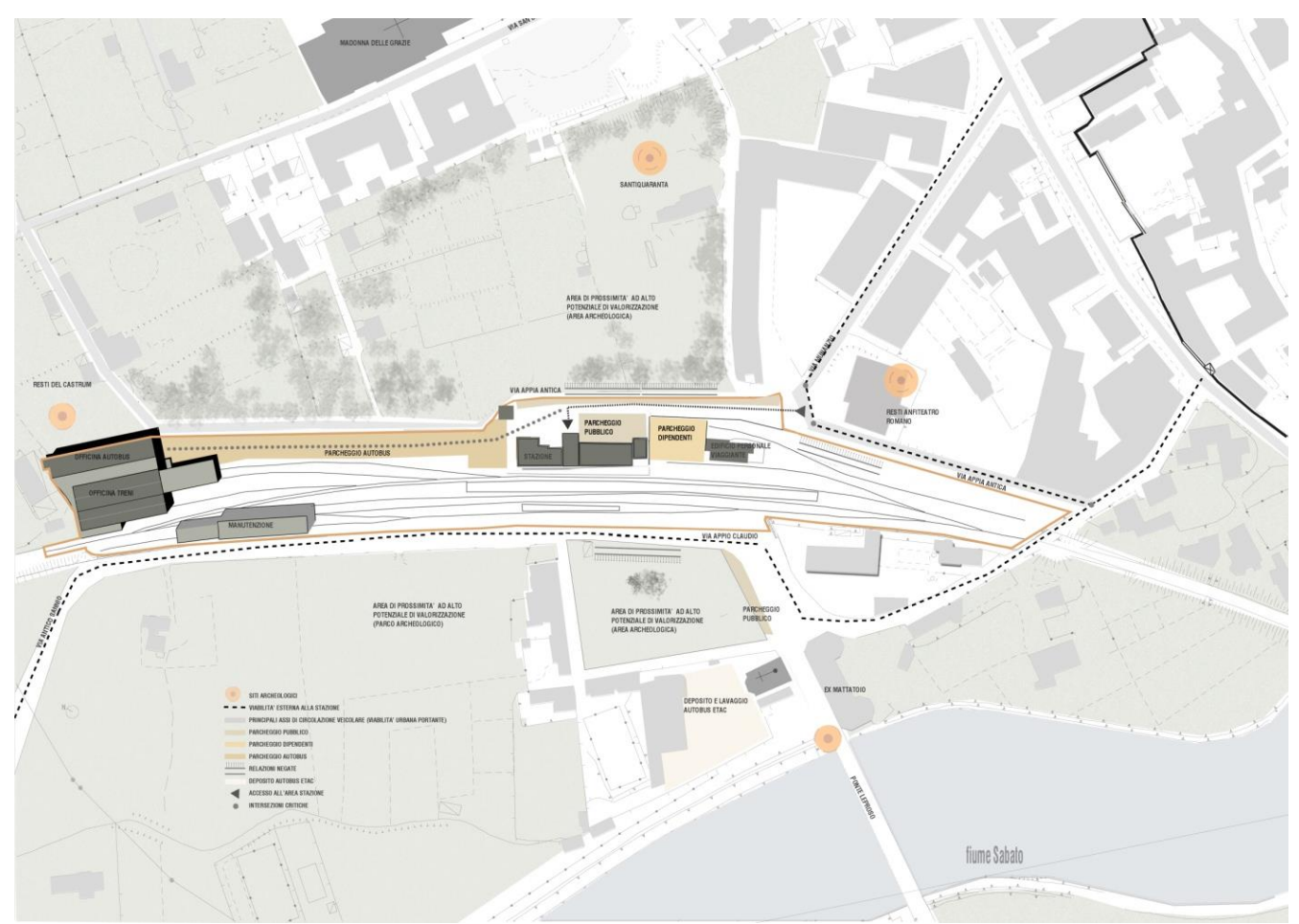

Figure 2. A New System of Relationships: Interconnected Layers and Breaking Margins. General Plan (Author Arch. Marina Di Iorio)

This same view was taken some years ago by the winning group of the competition for another significant area of the city of Benevento, involving the Roman Theatre, where it is stated that "the identification of circumscribed interventions prevails, however, the broader debate that it focuses on a theme that can be summed up by one word: connections. In Benevento, urban connections take on the character of urgent need" ${ }^{3}$.

Returning to Benevento Appia, the numerous excavations carried out over the years in this area and the many archaeological, that dot this part of the city, testify the presence of an early settlement of the Sannitic port between the San Lorenzo gate (now undetectable) and the area of Cellarulo, place of ancient settlement, of great importance in Roman times, in reference to which there were the bridges Leproso and Maior, infrastructure of a network of the Roman period, centered on the Via Latina and on the Via Appia.

In this area, an exceptional archaeological presence, only partly came to light, which is the Roman amphitheater of the city of Benevento, built probably

3. See Project report by Pasquale Culotta (leader), in Città di Benevento. Progetti a concorso. Riqualificazione e valorizzazione di piazza Cardinal Pacca, Bagni, Teatro Romano e calata Olivella (Naples: Clean, 2006) 40. 
in the first century AD. The remains of this important building were casually found between 1985 and 1995, even the radial walls of the auditorium and one of the annular hallways built in mixed work and tiles. Systematic excavations concerned the area in 1998, then interrupted and currently in conditions of neglect, although the City of Benevento has launched a project to redevelop the abandoned settlement Metalplex, with the highlighting of the remains of the amphitheater, on which the Benevento Appia station has largely been built.

The renewal of evident traces of the Benevento amphitheater, in a marginal position referring to the compact city, but with a large possibility of obtaining the shape and the dimensions, allows the development of a reflection on the intervention logics feasible in this particular situation. This, taking into account the peculiarities of the amphitheater, for which often "function is abandoned, but the shape-amphitheater maintains its relevance, because it is so suggestive, to offer opportunities for continual renewal" 4 .

On the other hand, "on Benevento affect the active presence of a history not formalized in styles or hegemonic scenarios and the variety of materials scattered through the town. The city, as a few in Italy, looks like a section through the time when everything might emerge, and where much is revealed, such as inclusion and addition" 5 .

This is also the situation of the Benevento Appia station, where the issue of the rationalization and modernization of the railway, even with significant changes to the rail level, referring to the station and the different areas that directly or indirectly gravitate to it, ultimately intertwines with that highlighted and enhances the historical and archaeological heritage. For a completely different scale, this same theme is further developed in the competition for the node infrastructure Yenikapi in Istanbul, where it "is expected to solve the problem of mobility in an urban area inhabited by more than 14 million inhabitants, placing in the expanse central Aksaray a series of new infrastructures in order to create a cultural laboratory, which holds within the passages of urban history, in all the stages of its development: from ancient presences to the enhancement of the ancient port of Theodosius and the archaeological heritage connected to it" ${ }^{6}$.

In the Benevento Appia station area, the theme is to interpret, in an innovative manner, the issue of the overlapping between the railway and archaeological remains, which so far has resulted in the concealment and destruction of the ancient remains and especially those of the amphitheater. To do this you need to properly address the issue of relations between the different components of the area, starting from the re-reading and re-definition of the relationship high-low: in other words, we need to work on the theme of layering (see Figure 3).

4. Herman Hertzberger, Flexibility and polivalency (Ekistics, 1963), 238-39.

5. Alberto Ferlenga et al., Una sezione attraverso il tempo, in Città di Benevento. Progetti a concorso. Riqualificazione e valorizzazione di piazza Cardinal Pacca, Bagni, Teatro Romano e calata Olivella (Naples: Clean, 2006) 56.

6. Federica Morgia, Atlante dei paesaggi archeologici, in Paesaggi di rovine paesaggi rovinati, ed. A. Capuano (Macerata: Quodlibet, 2014) 353. 


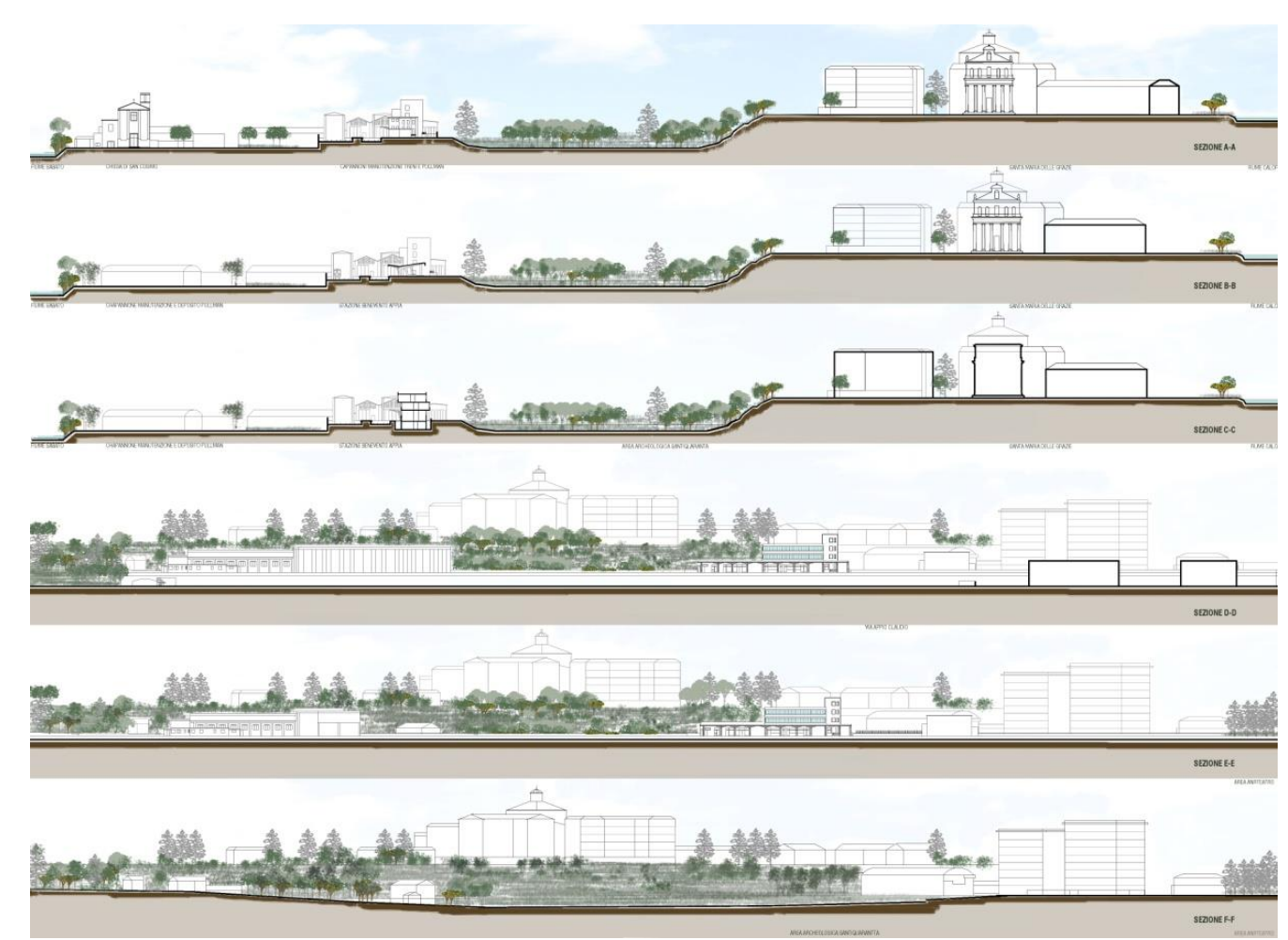

Figure 3. A New System of Relationships: Interconnected Layers and Breaking Margins. Sections (Author Arch. Marina Di Iorio)

Among the archaeological plan, the plan of the "iron" and with the levels on which it is currently constructed in the city of Benevento it is possible to establish very significant relations, interpreting them as compositions of planslayers, which mark the presence of the remains and at the same time bring into communication public spaces and archaeological spaces.

Ultimately the ancient (archaeological) element will play through the connection mechanisms that can involve several layers and levels of the city, aiming to build completely new urban reference $\operatorname{sites}^{7}$ (see Figure 4).

Working in this direction means making the railway area "crossed", clearly exceeding the block-logic that characterizes it. It is time to make a significant typological transformation of the station, with the aim of building a small "loop", as it indeed happened in many cities. Benevento comes to achieving a path that technically improves the accessibility to the station from different directions, but also an urban path, able to connect the area to the Leproso bridge with the area of the Madonna delle Grazie church, crossing the archaeological area of Cellarulo, also in perfect accordance with the terms of the recent urban plans, which arrange the area in the archaeological park.

7. Cfr. Pasquale Miano, Indagine archeologica e programma architettonico, in Paesaggi di rovine paesaggi rovinati, ed. A. Capuano (Macerata: Quodlibet, 2014). 


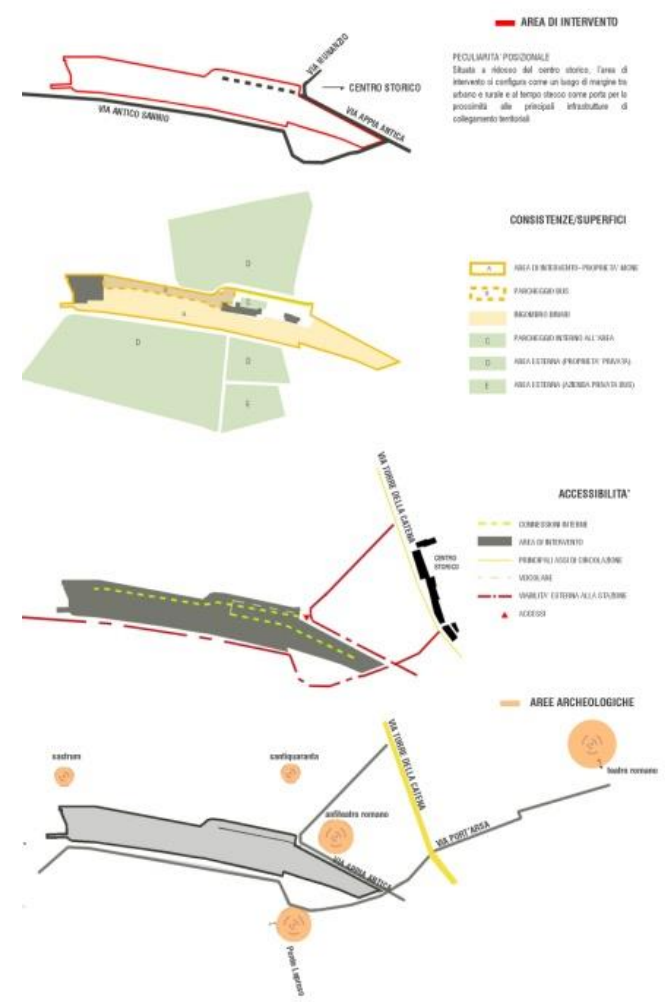

Figure 4. A New System of Relationships: Interconnected Layers and Breaking Margins. Schemes (Author Arch. Marina Di Iorio)

The path, which in some places can expand with the raised platformviewpoints, will rediscover the archaeological traces scattered in the area, marking a new door between the historic city and the marginal city through all the archaeological areas arranged in this area, yield accessible, through the introduction of connecting elements between the levels. In this view you can resume the way of thinking of Andreina Ricci about the archaeological sprawl, which is particularly effective in this case: "each residual fragment, scattered in the current settlement refers only to itself. Yet as if they were phrases seemingly meaningless [...] these units in their own right, are waiting to be combined into paths and sequences" 8 . The archaeological fragments are often included in the ruined landscapes of contemporary settlements, but there is a need to look at these situations in an architectural way, understand the mechanisms of continuity and update the archaeological maps.

The second step is to break the fences, simultaneously redesigning the border of the archaeological area, but also those of the station: the station area could eventually open up to the area of the Amphitheatre-former Metalplex, also this often understood as an independent area from the infrastructure problems, as it ultimately occurred in a design contest a few years ago 9 . The

8. Andreina Ricci, Attorno alla nuda pietra (Rome: Donzelli Editore, 2006), 148.

9. Cfr. Antonio Ferlenga and Fernanda De Maio, Consultazione internazionale di idee nell'area ex Metalplex di Benevento. Progettare nella storia. Realizzazione di un polo di formazione sui beni e attività culturali (Milan: Mondadori, 2006). 
goal is to achieve a long walk through the excavations and the few remains of the ancient amphitheater, which were recovered. "This connections game allows breaking and completely refuting the idea of archaeology in fenced cities, as the archaeological park, a mono-functional and specialized place removed from the urban dynamics. With the breaking of the edge of the archaeological area, enclosure becomes a transition system with variable thickness, walls, paths, entrances and public spaces, again directly related to the ruins" ${ }^{10}$.

On this basis it will be possible to establish a layered urban connection, consisting of a sequence of open spaces, in which the archaeological remains are completely involved in a new mechanism of interaction of different heights. This will also overcome the different levels and with the area adjacent to the Leproso bridge, the Church of St. Cosmas and former slaughterhouse, where the new bus terminal can be placed, also near the Santi Quaranta area and the Madonna delle Grazie church, in the direction of which the parking can be located. This will also able to insert this urban crossing as a significant element of "a system of walking, which is accomplished daily by citizens, who affirm and consolidate the identity and sense of belonging to the place"11.

The idea is of building a new urban space, which, for ease of terminology, we can define as the park. In fact it is a set of areas in which the archaeological, agricultural and urban aspects will be strongly intertwined, even with hydrogeological and re-naturalization interventions. The park will gradually open up to the suburban area and to the city, through a light infrastructure, an integrated system of sustainable mobility, which is configured as a hybrid between public transport and alternative modes of transport, that can effectively address the issue of accessibility for all.

In the park, the terminal and the car park areas will be integrated to the landscape and connect with each other and with the station square, released from all logistic functions, to be able to design an archaeological viewpoint, hinge between archeology, landscape and the cities, so that the building of the station, properly reconfigured will return its lost centrality.

This makes it possible to achieve the dual objective of connecting the site at different scales (regional and urban) through the construction of an interchange hub, able to weave numerous relationships with major points of the urban context and places scattered in the open territory, in which the station will become one of the main polarity.

The theme of the linear connection element, which contributes to the breakdown of the archaeological and rail fence, is open to different design interpretations: in particular have been taken into account two project ideas, one that works on a path partially buried and another on a path partially raised. Both proposals interpret the theme of urban connection at several levels, starting from the conditions of the relocation of the bus station and its storage related to a new organization of spaces resulting from the modification of the

10. Miano, Indagine archeologica e programma architettonico, 259.

11. Maria Margarita Segarra Lagunes, Archeologia e metropolitana, in Confronti 2/3 Infrastruttura urbana e città storica (2013), 38. 
surface of the rail, the movement of the car with the redesign of the square of the station and the extension of the railway building, intended to exhibition and commercial spaces (see Figure 5).
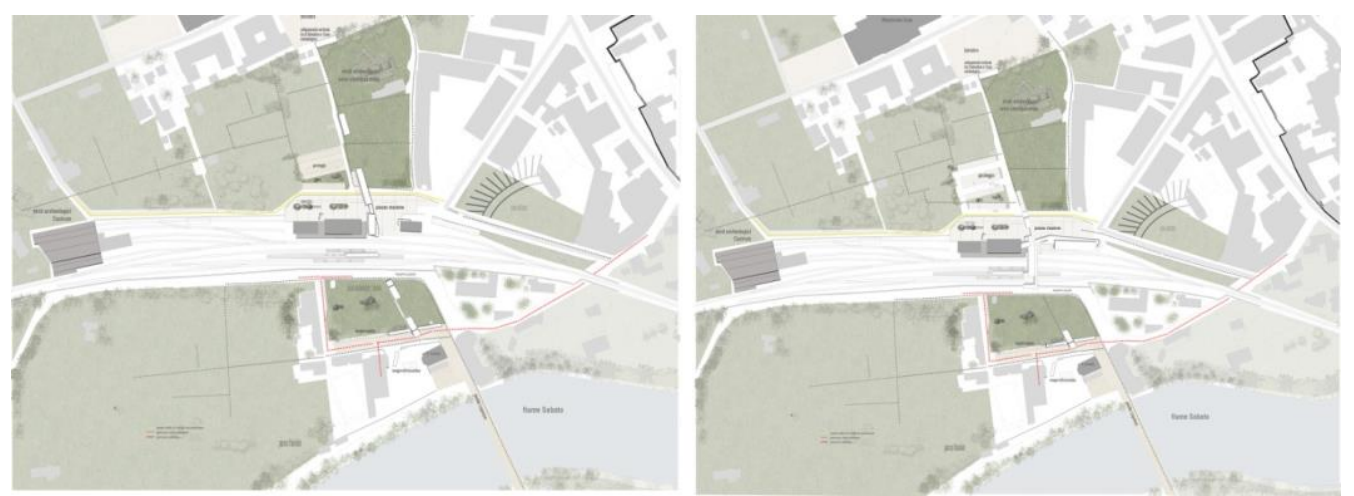

Figure 5. The New Project Proposals and Alternatives (Author Arch. Marina Di Iorio)

In particular, the transformation of the rail level inevitably determines the relocation of some functions of the station with the need to define a flow that leads passengers and staff directly to the new platform, with the displacement of the ticket, which must be well-connected to the intermediate tracks.

In the solution of the crossing of the railway with an underground path, which also houses the new ticket office, the station square, and true urban center, may acquire the character of interrelation element, being closely linked to the amphitheater area and to other archaeological parts now completely separate. The new connection will be able to enter more directly in contact with the archaeological findings in, by seeking a dialogue with the ruin, through the continuation of excavation operations, the results of which are not absolutely predictable: this should not be seen as a limit, but rather as a potential that in such articulated areas must necessarily assume the character of the process ${ }^{12}$ (see Figure 6).

12. Jose-Ignacio Linazasoro writes "The ruin introduces the concept of architecture as a process," in Jose-Ignacio Linazasoro, Rovine, in Ricomporre la rovina, ed. A. Ugolini (Florence: Alinea, 2010), 17. 

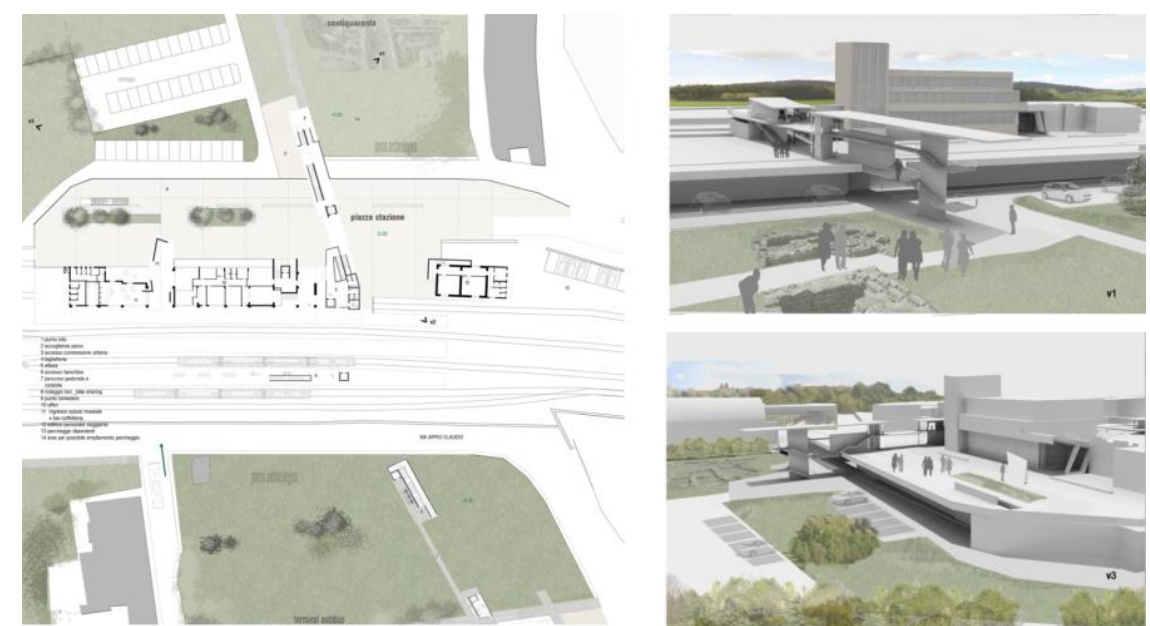

Figure 6. Proposal for a Connection to the Underground Level (Author Arch. Marina Di Iorio)

This wide bridge space inside the station, mostly made of glass, will be accompanied by a walkway, which allows easy access to the station both by the side of the Leproso bridge and by the city, in the final connecting urban parts separated before (see Figure 7).

Even in the second proposal, the path is installed on different levels, articulating on layered and strategically rotated planes, so that thelandscape can be discovered from different heights and perspectives. The new element is developed as a bridge (with a height above the rail level of about $7.50 \mathrm{~m}$ ) jumping over the railway and assuming the role of the hub of the station. Here a new ticket office and a large waiting area will be located, which will also be the access path to the dock.
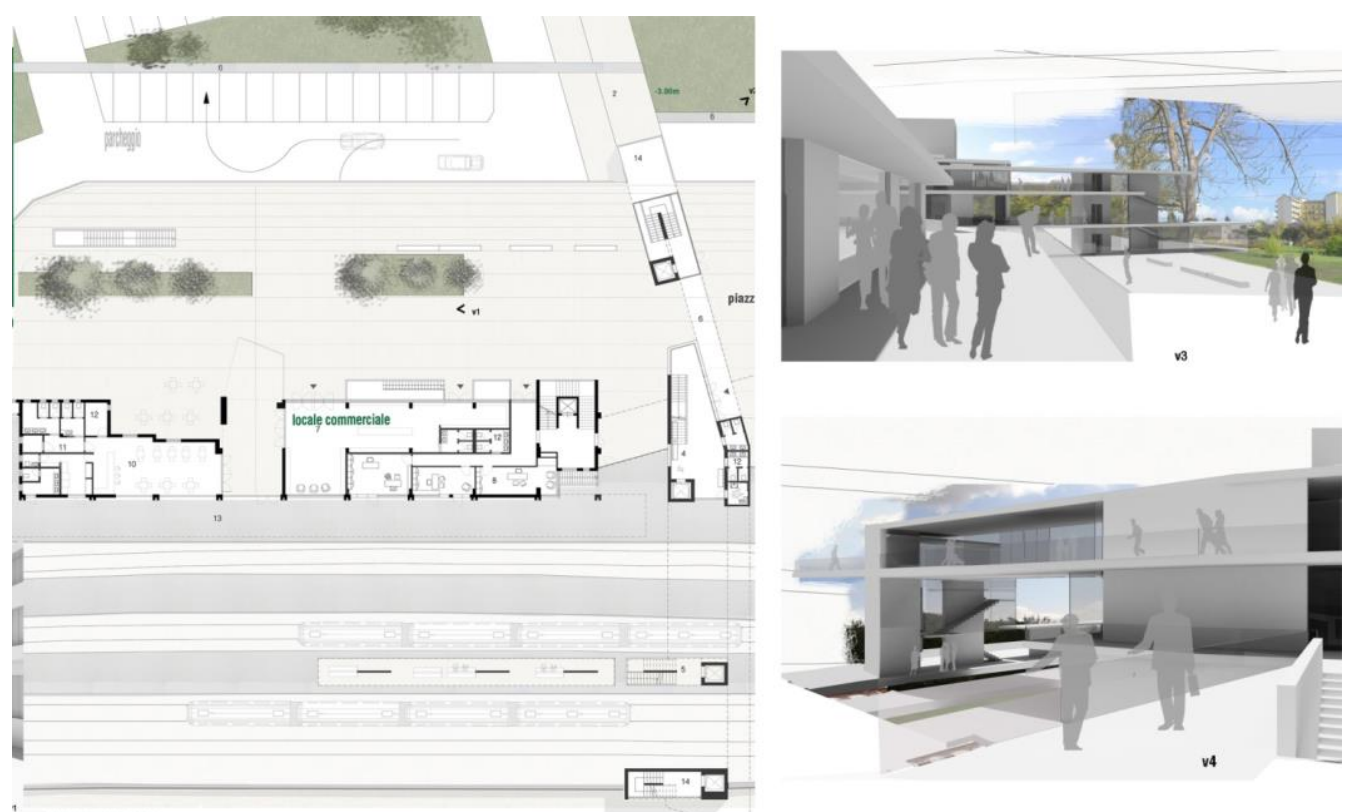

Figure 7. Proposal for Connection to the Raised Level (Author Arch. Marina Di Iorio) 
The significant gap between the bridge and the square, approximately of 10 meters, can be solved with a tower element, which also allows the discovery of the environment with large landings of overlooking. The square becomes a large belvedere, which plays an important role in the system of connections. Finally, also to the urban area of the Madonna delle Grazie, the ascent solution can be followed, creating an additional connecting urban trunk and a crossing to the archaeological area (see Figure 8).
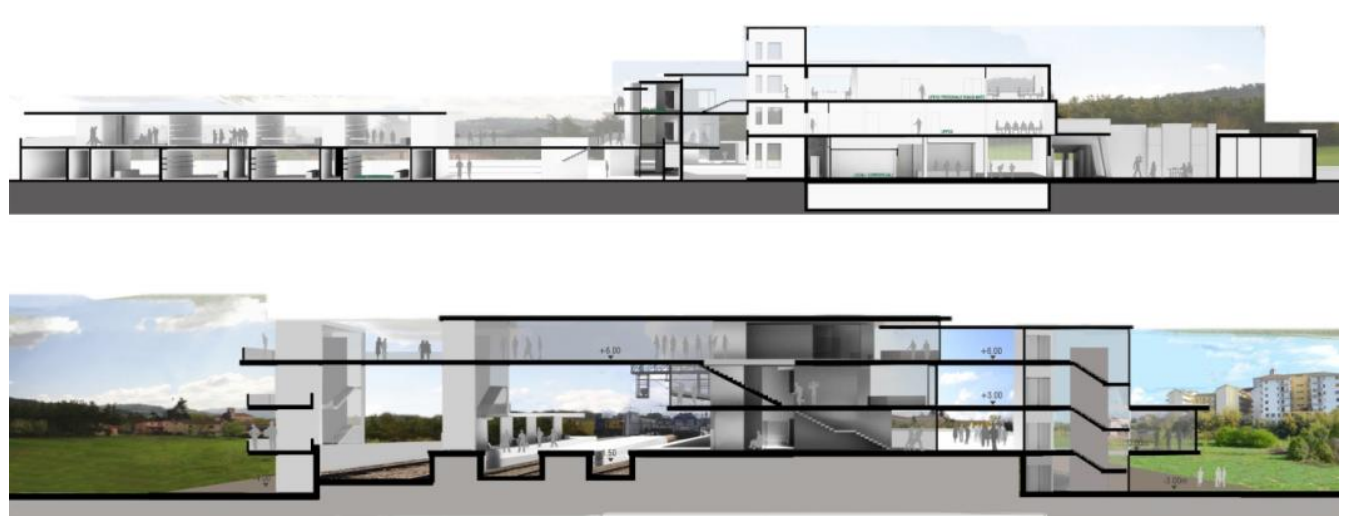

Figure 8. Proposal for Connection to the Raised Level. Sections (Author Arch. Marina Di Iorio)

As emphasized by Francesco Cellini, referring to his plan for Yenikapi, first cited, "the spaces of the station work for citizens, engaged in their daily activities as users of the means of the transport can, since the lower level of the station, receive the remains of the ancient city, cross them, intrigue until visit and understand them, accessing easily and immediately the museum circuit. Making sure that when they emerge on the city surface, they can capture the true size and scale of the old port" ${ }^{13}$.

\section{The Excavation of the Amphitheater and the New Space Station}

The reconfiguration of the Benevento Appia station, with the involvement of the archaeological area in the new organization of urban routes and connections, could be further developed, also involving the archaeological areas of the amphitheater that, as a result of further excavations, probably will be highlighted in the coming years ${ }^{14}$ (see Figure 9).

13. Francesco Cellini and Maria Margarita Segarra Lagunes, Yenkapi: una sfida tra patrimonio e contemporaneità, in Confronti 2/3 Infrastruttura urbana e città storica (2013), 125.

14. Questo sviluppo progettuale, oltre che nella Convenzione prima citata, è stato affrontato nella tesi di laurea di Germano Sessa, Riconfigurazione dell'area della Stazione di Benevento Appia, di cui sono stato relatore. This design process, as well as in the agreement cited above, has been studied in the thesis of Germano Sessa, Reconfiguration of the station Benevento Appia, of which I was the supervisor. 


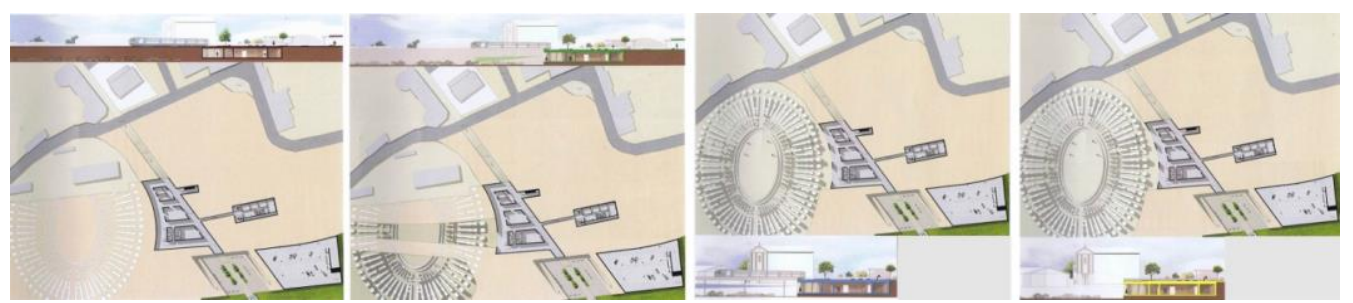

Figure 9. The Excavations of the Amphitheater and the New Spaces of the Station (Author Arch. Germano Sessa)

Referring to the solution of an underground crossing of the railway area, you may provide an expanded and underground floor connected to the station, so as to get significantly close to the amphitheater remains: a mediation element between the station spaces and the archaeological spaces, which has the task of connecting them. Such interventions would not require any alteration of the rail logistics.

In a second step the excavation operations of that part of the amphitheater not covered by the infrastructure (the railway itself, the road and some private buildings) could be made. This action would allow the opening of a new access on an excavations portion from the new underground entrance to the station, ensuring that the direct use of the parts of the amphitheater have undergone the processes of excavation.

Ultimately "archaeological preexistences, placed in a new system of urban relationships, become a place of transition, able to mediate in the delicate relationship between urban artifice and landscape. Through new relationships between levels under and over imposed on the ground level, along the vertical axis of the various layers, a new system of relations is determined that governs the relationship high-low and is inclined to expand horizontally, involving significant urban parts" ${ }^{15}$.

More significant excavation phases, able to invest the amphitheater globally, must inevitably involve the railway areas. Another alternative is clear and recurs in many situations when we face the problem of the elimination of the railway: to build a railway bridge that can completely bypass the archaeological area or divert the railway line, so as to completely clear the amphitheater.

Given that such interventions induce a level of complexity that can hardly be addressed without very substantial investments, unlike other interventions first presented, more feasible. However, it seems useful to compare these solutions to understand critical issues.

The bridge has objective difficulties of realization and could also undermine the integrity of the archaeological findings, although it has the advantage of allowing the coexistence of the archaeological system with the

15. Pasquale Miano, Ricerche e sperimentazioni: i risultati di due workshop del Dottorato di Ricerca in Progettazione Urbana e Urbanistica dell'Università Federico II di Napoli, in Città tra terra e acqua. Esplorazioni e progetto nel Dottorato di Ricerca, ed. P. Miano and M. Russo (Naples: Clean, 2014), 20. 
infrastructural system, to propose a stratigraphic logic, closer to the settlements sequence of this urban portion of Benevento.

The deviation of the railway would rather have the advantage of preserving the archeology, but, perhaps, again, away from the thickness of urban and regional issues, not to mention the burden of the work. This proposes, in many ways, the misconception that only the excavation and possibly with the overall reconstruction of the entire amphitheater, will determine the conditions for the full and proper use of the ancient monument. It is clear that, as well as the program design must be continuously adapted to cognitive elements that emerge from the archaeological research, "the discipline of archeology should not chase an alleged scientific nature but the reality, taking a rigid position, but must be able to measure other points of view and different readings. Among these, especially important are the settings that are configured not only as reconstructions of the ancient, but as knowledge and interpretation of territories and landscapes marked by the archaeological presence" ${ }^{16}$, accepting the fragmentary and partiality, aspects that can be a great incentive to continue the researches, continually renewing the content and the stories of places.

\section{Conclusions}

The case of the Benevento Appia station brings into play the problems of archeology in the redefining and upgrading of the rail infrastructure systems, which are required in large parts of the Italian territory.

The need to create new spaces connected to the stations and rail infrastructure, able to escape to a sterile mono-functional mechanism, now completely outdated, appears evident. This does not mean, and the case of Benevento is striking in this sense, that we should not work to solve logistical problems, creating an interchange fully functional. However, the theme of the multi-functionality of new railway spaces, in which the content of various kinds can also be a regenerative and attractiveness factor, is central. It can play a very important role among these archaeological areas, as they allow to highlight a significant split of the city history and to replenish threads that were completely severed in the transformation of the city.

In terms of design, the theme of re-composition of the cut, of the break created by the railway infrastructure becomes the construction of even partial continuities, able to put together archaeological fragments belonging to different times of the city, and to relate them to other places and urban emergencies.

In the situation of Benevento Appia the theme of connection at various altitudes and at different levels significantly increases the rail logistics, but also to connect broken parts of the city and restore the meaning to the ancient presence in the contemporary territory.

16. Ibid, 256. 
This may be just part of the rationalization and modernization of the railway infrastructure, by introducing relationship mechanisms between the layers and breaking the rail and archaeological fences, considerably approaching the station area to the amphitheater.

Ultimately, working on a strategy of urban reconnection, able to involve the railway infrastructures and archaeological sites, means to build and develop a project of the public space, in which the distinctions between the different aspects tends to gradually lose its meaning: a spatial unit, multifaceted and varied, in which the presence of different elements, which are unintentionally overlapped throughout history, determines a dynamic and changing condition, opening up new and unexpected processes.

\section{Bibliography}

Capuano, Alessandra (ed.). Paesaggi di rovine paesaggi rovinati. [Landscapes of Ruins Ruined Landscapes.] Macerata: Quodlibet, 2014.

Cellini, Francesco and Maria Margarita Segarra Lagunes. Yenkapi: una sfida tra patrimonio e contemporaneità [Yenikapi: a contest between heritage and modernity.] In Confronti 2/3 Infrastruttura urbana e città storica, 125. 2013.

Culotta, Pasquale. Project report. In Città di Benevento. Progetti a concorso. Riqualificazione e valorizzazione di piazza Cardinal Pacca, Bagni, Teatro Romano e calata Olivella, 40. Naples: Clean, 2006.

Ferlenga, Antonio and Fernanda De Maio. Consultazione internazionale di idee nell'area ex Metalplex di Benevento. Progettare nella storia. Realizzazione di un polo di formazione sui beni e attività culturali. [International Consultation of ideas in the former Metalplex of Benevento. Design in history. Creation of a training center on cultural heritage and activities.] Casabella N.744. Milan: Mondadori, 2006.

Ferlenga, Alberto et al. Una sezione attraverso il tempo. [A section through time.] In Città di Benevento. Progetti a concorso. Riqualificazione e valorizzazione di piazza Cardinal Pacca, Bagni, Teatro Romano e calata Olivella, 56. Naples: Clean, 2006.

Hertzberger, Herman. Flexibility and polivalency. Ekistics, 1963.

Linazasoro, Jose-Ignacio. Rovine. [Ruins.] In Ricomporre la rovina, 17. Edited by Andrea Ugolini. Florence: Alinea, 2010.

Mazzoni, Christina. Stazioni, architetture 1990-2010. [Stations, architecture 19902010.] Milan: Federico Motta Editore, 2001.

Miano, Pasquale. Indagine archeologica e programma architettonico. [Archaeological and architectural plan survey.] In Paesaggi di rovine paesaggi rovinati. Edited by Alessandra Capuano. Macerata: Quodlibet, 2014.

Miano, Pasquale. Ricerche e sperimentazioni: i risultati di due workshop del Dottorato di Ricerca in Progettazione Urbana e Urbanistica dell'Università Federico II di Napoli. [Research and experimentation: the results of two of the PhD workshop of Research in Urban Design and Planning, University of Naples Federico II.] In Città tra terra e acqua. Esplorazioni e progetto nel Dottorato di Ricerca. Edited by Pasquale Miano and Michelangelo Russo. Naples: Clean, 2014. 
Miano, Pasquale and Michelangelo Russo (eds.). Città tra terra e acqua. Esplorazioni e progetto nel Dottorato di Ricerca. [City between land and water. Exploration and project PhD.] Naples: Clean, 2014.

Morgia, Federica. Atlante dei paesaggi archeologici. [Atlas of archaeological landscapes.] In Paesaggi di rovine paesaggi rovinati, 353. Edited by Alessandra Capuano. Macerata: Quodlibet, 2014.

Palmieri, Pasquale. Città di Benevento. Progetti a concorso. Riqualificazione e valorizzazione di piazza Cardinal Pacca, Bagni, Teatro Romano e calata Olivella. [City of Benevento. Calls for project proposals. Redevelopment and enhancement of Piazza Cardinal Pacca, Bath, Teatro Romano Olivella in Catalan.] Naples: Clean, 2006.

Ricci, Andreina. Attorno alla nuda pietra. [Around the bare stone.] Rome: Donzelli Editore, 2006.

Segarra Lagunes, Maria Margarita. Archeologia e metropolitana. [Archaeology and metro.] In Confronti 2/3 Infrastruttura urbana e città storica, 38. 2013. 